\title{
Entegre Raporlama: Yayınlanan Raporlar Üzerine Bir Araştırma*
}

\section{Integrated Reporting: A Research on Published Reports}

\author{
Tolga ORAL, ${ }^{\mathrm{a}^{* *}}$ Hakan ERKUŞ ${ }^{\mathrm{b}}$ \\ ${ }^{a}$ Dr. Öğr. Üyesi, İnönü Üniversitesi, İiBF, İşletme Bölümü, 44280, Malatya/Türkiye. \\ ORCID: 0000-0002-7173-8171

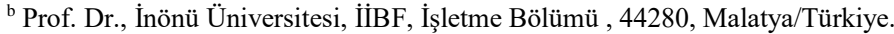 \\ ORCID: 0000-0003-0925-9396
}

\section{MAKALE BİLGISİ}

Makale Geçmişi:

Başvuru tarihi: 31 Ekim 2018

Düzeltme tarihi: 11 Aralık 2108

Kabul tarihi: 25 Aralık 2018

Anahtar Kelimeler:

Finansal Bilgi

Finansal Olmayan Bilgi

Entegre Raporlama

\section{A R T I C LE INFO}

Article history:

Received 31 October 2018

Received in revised form 11 December 2018 Accepted 25 December 2018

\section{Keywords:}

Financial Information

Nonfinancial Information

Integrated Reporting
ÖZ

İşletmeler, faaliyetleri sonucunda ürettikleri bilgileri raporlar aracılığıyla ilgi duyanlara sunmaktadır. Bu bilgiler, hem finansal hem de finansal olmayan niteliktedir. Finansal bilgiler, muhasebe bilgi sistemi vasıtasıyla mali tablolarda sunulmaktadır. Finansal olmayan bilgiler ise kurumsal raporlar aracılığıyla iletilmektedir. $\mathrm{Bu}$ durum üretilen bilgileri kullanan kesimlerin, finansal ve finansal olmayan bilgileri farklı kaynaklardan sağlamalarına neden olmaktadır. $\mathrm{Bu}$ çalışmanın amacı, entegre raporlamayı, işletmelerin yayınladıkları raporları analiz ederek açıklamaktır. Bu amaç doğrultusunda entegre raporlama kavramı teorik olarak açıklandıktan sonra Fortune dergisinin yayınladığı 2016 yılı dünyanın en büyük 500 İşletme içinde yer alan 50 işletmenin entegre raporları nitel analiz yöntemlerinden içerik analizine tabi tutulmuştur. Araştırma sonucunda, raporlarda içerik ögelerinin tamamına ilişkin bilgi sunulurken, kurumsal genel görünüm ve dış çevre konusunda daha fazla açıklama yapıldığı görülmüştür.

\section{A B S T R A C T}

Businesses present the information produced as a result of their activities by reports to interested parties. These information is both financial and non-financial. Financial information is presented in the financial statements through the accounting information system. Non-financial information is communicated through corporate reports. This situation leads to the acquisition of financial and non-financial information from different sources for those who use this information. The aim of this study is to explain the integrated reporting by analyzing the reports published by the companies. In accordance with this purpose, after theoretically explaining the integrated reporting concept, the integrated reports of the 50 businesses in the world's largest 500 businesses published by Fortune magazine in 2016 have been analyzed by content analysis which is one of the qualitative analysis methods. While the integrated reports provide information on the complete content more explanations are given about the corporate overview and the external environment.

\section{Giriş}

Dünya'da yaşanan küreselleşme serüveni ve teknolojik değişim, işletmeleri de etkilemiştir. Büyük ölçekli işletme sayısının artması ve küresel boyutlu iş hayatının başlaması, bu etkiler arasında yer almaktadır. İşletme sayısı ve büyüklüklerinde meydana gelen artış işlem sayısı ve hızını artırmış, işletme faaliyetlerinin daha yakından izlenmesini gerekli kılmıştır. İşletmelerin bu denli bir gözetim altına alınması, faaliyetlerinin şeffaf ve hesap verilebilir bir şekilde açıklanmasını gerekli kılmıştır. İşletme performanslarının sadece finansal olarak açıklanmasının, yaşanan bazı denetim ve şirket skandalları ile birlikte yetersiz hale geldiği görülmüştür. Şirketlerin finansal performansının yanında, finansal performansı etkileyen sosyal, kurumsal ve çevresel performanslarının da açıklanması gerekliliği dile getirilmiştir. $\mathrm{Bu}$ gereklilik sonucunda çoğu işletme temelinde finansal raporlamanın yer aldığı kurumsal raporlar(kurumsal sosyal sorumluluk raporları, sürdürülebilirlik raporları vb.) yayınlamaya

\footnotetext{
*Bu çalışma, 2018 yılında Prof. Dr. Hakan ERKUŞ danışmanlığında İnönü Üniversitesi Sosyal Bilimler Enstitüsü İşletme Ana Bilim Dalı'nda Tolga ORAL tarafından yazılan "Entegre Raporlamada İçerik Analizi” başlıklı doktora tezinden türetilmiştir.

** Sorumlu yazar/Corresponding author

e-posta: tolga.oral@inonu.edu.tr
} 
başlamıştır. $\mathrm{Bu}$ raporlar daha çok işletmenin finansal olmayan performans sonuçlarını açıklamaya çalışmaktadır. Ancak bu raporlar, finansal sonuçlardan bağımsız olarak sunulması, işletmenin gelecek vizyonunu tam yansıtmaması ve işletme ile ilgili bilgilerin birden fazla kaynaktan sağlaması gibi nedenlerle tam olarak ihtiyaca cevap verememiştir. $\mathrm{Bu}$ bakış açısıyla hem finansal hem de finansal olmayan bilgileri tek bir çatı altında bilgi kullanıcılarına sunmayı hedefleyen entegre raporlama kavramı ortaya çıkmıştır.

Entegre raporlama, bütüncül bir bakış açısıyla işletme faaliyetlerinin gerçekleştirilmesi sürecinde ortaya çıkan değer ve bu değer yaratma sürecine etki eden faktörleri finansal ve finansal olmayan performans sonuçları ile birlikte sunmayı hedeflemektedir. Bu hedef doğrultusunda işletmenin faaliyetlerini ve bu faaliyetleri geçekleştirmek için kullandığı sermaye ögelerini, işletme faaliyetleri neticesinde sermaye ögelerinde meydana gelen değişimleri açıklamaya çalışır. Günümüze kadar süre gelen raporlama düşüncelerine yeni bir soluk katmayı misyon edinen entegre raporlama henüz yeni bir raporlama yaklaşımı olmasına rağmen önemli bir ivme kazanarak yaygınlaşmaya başlamıştır. Dünya genelinde çoğu ülkede gönüllü olarak sunulan bu rapor, Güney Afrika Cumhuriyeti'nde borsada işlem gören şirketler için zorunlu tutulmuştur. Bu açıdan entegre raporlama konusunda Güney Afrika Cumhuriyeti önde gelen ülke konumundadır. Ülkemizde ise entegre raporlama konusunda 2015 ve 2016 y1llarında ilk entegre raporlar yayınlanmış olup entegre raporlama çalışmaları devam etmektedir.

$\mathrm{Bu}$ çalışmanın amacı, raporlama konusunda yeni bir bakış açısı sunan entegre raporlama kavramını açıklayarak, yayınlanan raporlar çerçevesinde analiz etmektir. Buradan hareketle Fortune Global 5002016 yılı listesinde entegre raporlama yapan 50işletmenin 2016 yılında yayınladıkları raporlar içerik analizine tabi tutulmuştur.

\section{Bilgi ve Raporlama}

Bilgi, Türk Dil Kurumu (TDK) Genel Türkçe Sözlüğü'nde; "İnsan aklının erebileceği olgu, gerçek ve ilkelerin bütünü; öğrenme, araştırma veya gözlem yolu ile elde edilen gerçek" olarak iki farklı şekilde tanımlanmaktadır. Bu tanımlamada bilginin biçimi konusunda bir ifade bulunmamaktadır. Metin, çizim, resim ya da fotoğraf şeklinde de karşımıza çıkmaktadır (Özdemir, 2013:158).

Bilgi kavramı ile bazı kavramlar zaman zaman birbirinin yerine kullanılmaktadır. Söz konusu kavramlar çoğu zaman aynı şeyi ifade etmelerine rağmen aralarında önemli farklılıklar bulunmaktadır. Bu kavramlar veri ve enformasyon olarak karşımıza çıkmaktadır. Veri kavramı çoğu kez bilgi kavramı yerine kullanılır. Ancak veri, işlenmemiş ham kayıtlar olarak tanımlanmaktadır (Ala vd, 2016:143). Türk Dil Kurumu (TDK) Genel Türkçe Sözlüğü’nde veri, "bir araştırmanın, bir tartışmanın, bir muhakemenin temeli olan ana öge, muta, done" olarak tanımlanmıştır. Veriyi hiçbir işleme uğramamış ve değiştirilmemiş kayıtlar topluluğu olarak ifade etmekte mümkündür. Diğer bir kavram olan enformasyon ise, belirli bir şekle dönüştürülmüş, anlam kazanmış ve yararsağlayan veri olarak tanımlanabilir (Laudon ve Laudon, 1998:8). Veriden farklı olarak enformasyon amaç taşımaktadır. Belirli bir amaç doğrultusunda verinin işlenmesi olarak ifade edilebilir. Bilgi kavramı ise bu ifade edilen kavramlardan daha geniş bir anlam taşımaktadır. Bhatt'a (2002:32) bilgi, insan zihninin düşüncelere, kurallara, ilkelere ve enformasyona bilinçli bir şekilde anlam kazandırması olarak tanımlanmıştır. Başka bir anlatımla verinin işlenerek enformasyona dönüştürülmesi ve buna anlam yüklenmesi şeklinde ifade edilebilir.

\section{Entegre Raporlama}

Eccles ve Krzus (2010) entegre raporlamayı paydaşlarla iletişim kurmak için finansal ve finansal olmayan bilgileri birbiri ile ilişkilendirerek sunan rapor olarak tanımlamaktadır. Entegre rapor, organizasyonun stratejisinin, yönetiminin, performansının ve beklentilerinin dış çevre bağlamında kısa, orta ve uzun vadede değer yaratılmasına neden olan kısa bir iletişim olarak tanımlanır (Ştefănescua et.all, 2016:548). Entegre rapor, işletmelerin zaman içinde nasıl değer yarattığını ifade eder ve finansal bilgileri çevresel, sosyal ve kurumsal bilgilerle birleştirir (Lai vd., 2016:165). Entegre raporlama, finansal ve finansal olmayan bilgileri bir araya getirerek, entegre düşünmeyi geliștirmeye, aralarındaki karşılıklı bağımlılıkların altında yatan nedenleri ortaya çıkarmaya, bilgi kalitesini geliştirmeye, işletmeyi etkileyen önemli meseleleri tespit etmeye çalışır. $\mathrm{Bu}$ durum da kaynakların daha iyi kullanılmasına yol açacaktır. Bütün bu unsurlar, entegre düşünce, karar verme ve kısa, orta ve uzun vadede değer yaratmaya odaklanmış faaliyetlere destek verir (Hurghis, 2017: 84). Entegre rapor, finansal raporlar ile sürdürülebilirlik raporlarında sunulan bilgilerin bir arada değerlendirilerek yorumlanması sonucunda ortaya çıkan özet bilginin sunulması olarak ifade edilebilir (Kaya, 2015:118; Eccles ve Saltzman, 2011:59). Tek rapor olarak da ifade edilebilen entegre rapor, işletme faaliyetlerine ilişkin finansal ve kurumsal raporların tek bir rapor olarak sunulmasıdır (Karğın vd., 2013:28).

Entegre raporlama işletme faaliyetlerinin sonuçlarını sosyal, ekonomik ve çevresel boyutta ele almakta ve bu sonuçların bir arada değerlendirilip sunulmasına dayanmaktadır (Altınay, 2016:57). Entegre raporlama, finansal ve finansal olmayan performans arasındaki ilişkiyi ortaya koymaya ve bu birbiriyle ilişkili boyutların pay sahipleri ve diğer paydaşlar için değer yaratma yeteneklerini açıklamaya çalışır (Buitendag vd., 2017:2). Entegre raporlama, işletmenin stratejisi, kurumsal yönetim anlayışı ve finansal göstergelerini sosyal, çevresel ve ekonomik açılardan bağdaştıran ve bunların değer yaratma sürecine katkılarını kısa ve anlaşılabilir birbiçimde sunulması olarak ifade edilebilir (Y1lmaz vd., 2017:97).

Tüm bu tanımlamalardan hareketle entegre raporlama, işletmenin finansal bilgileri ile finansal olmayan bilgilerini değer yaratma sürecinde birlikte değerlendirip ilgi duyanlara anlaşılabilir ve sade bir şekilde tek bir rapor halinde sunulması süreci şeklinde açıklanabilir.

\subsection{Entegre Raporlamanın Ortaya Çıkışı}

Yaşanan finansal krizler, finansal raporlamanın tek başına işletme performansını tam olarak yansıtamadığını, yatırımcıların ve paydaşların ihtiyacını karşılayamadığını göstermiştir. Aynı zamanda, dünya, küreselleşme ve ekonomilerdeki karşılıklı bağımlılıklar, teknolojideki gelişmeler, hızlı nüfus artışı ve artan küresel tüketim 
yüzünden değişmiş ve birçok işletme, yatırımcı ve devlet işletmenin kurumsal yönetimini ve performansını kısa, orta ve uzun vadede değerlendirmeye çalışmıştır. $\mathrm{Bu}$ durum finansal raporlamanın yanında kurumsal raporların sunulmasına yol açmıştır. Ancak kurumsal raporlama da tam anlamiyla finansal ve finansal olmayan bilgilerin birlikte açıklanmasına çözüm olamamıştır. Entegre raporlama ile kurumsal raporlamanın bu sorununa çözüm bulunmuştur (Bobitan ve Stefea, 2015:448-449).

Entegre raporlamanın ortaya çıkış sebepleri şöyle ifade edilebilir (Kaya, 2015:116):

- Bilgi kullanıcılarının işletmeyi değerlendirirken sadece finansal ya da sadece sosyal sorumluluklarına ilişkin tek bir ölçütle değerlendirmek istememesi,

- Halihazırda sunulan raporların bölümleri arasında tutarsızlıklar bulunması, raporların çok uzun olmasına karşın eksik bilgi sunması nedeniyle anlaşılabilirliğinin azalmas1,

- İşletmenin finansal performanslarının geçmişe dönük bilgiler sunması ve bunun geleceğe yönelik bir perspektif sağlamaması,

- Sürdürülebilirlik raporlarının gelecek yönelimli olması ve gerekli finansal bilgi sunmaması,

- İşletme hakkında bilgiye ihtiyaç duyanların finansal ve finansal olmayan bilgileri tek bir rapordan elde etmeyi istemeleri,

- Sürdürülebilirlik ve işletme hedeflerinin finansal göstergelerle desteklenerek bir arada sunulmasının güvenilirlik ve anlaşılabilirliği artıracağı beklentisi.

2010 yılından bu yana Güney Afrika'da entegre raporlama hızla gelişmiş ve 2013 yılı sonunda dünyanın ilk Uluslararası Entegre Raporlama Çerçevesi'nin yayınlanmasına yol açmıştır. Güney Afrika, Nelson Mandela ve Profesör Mervyn King'in oluşturduğu King Komisyonu'ndan başlayarak, entegre raporlamanın dünya çapında geliştirilmesine önemli ölçüde katkıda bulunmuştur (Buitendag vd., 2017:1).

\subsection{Entegre Raporlamanın Amac1}

Entegre raporlama, işletmenin stratejisi, kurumsal yönetimi ve performansı ile beklentileri hakkında, bileşik, organize ve faaliyet gösterdiği ticari, sosyal ve çevresel ilişkileri yansıtan bir şekilde bilgi sunarak diğer raporlama türlerinin baş edemediği zorlukların üstesinden gelmeyi hedeflemektedir (Frias-Aceituno vd., 2012). İşletmenin değerinin doğru ve güvenilir bir şekilde sunulmasını ve böylece sürdürülebilirliğin muhasebeleştirilmesini amaçlayan entegre raporlama, finansal raporlama ve sürdürülebilirlik raporlamasının farklı dünyaları arasında uzanan hibrid bir uygulamadir. (van Bommel, 2014). Entegre raporlama, bir işletmenin nasıl değer yarattığını ve bu değerin sürdürülebilirliğini bütünsel ve özlü bir biçimde anlatmayı amaçlamaktadır (Uluslararası Entegre Raporlama Konseyi (IIRC), 2011, 2013).İşletmelerin performanslarını altı farklı sermaye türüne (finansal, sosyal ve ilişkisel, entelektüel, üretilmiş ve insan ve doğal sermaye dahil olmak üzere) göre rapor etmesini isteyen entegre raporlama, bu sermayelerin işletmenin değer yaratma stratejisinde nasıl birleştiğini açıklamaya çalışmaktadır. (IIRC, 2013) Entegre raporlamanın amacı bir işletmenin stratejisini, kurumsal yönetimi, iş modeli ve sermaye ögeleri ile birleştirerek yarattığı değeri paydaşlara iletmektir (Tianyuan vd., 2017: 331). Aynı zamanda entegre raporlama, kullanıcılara önemli bilgiler sunarak işletmenin stratejisi, süreçleri ve uzun dönemli firsat ve tehditleri hakkında açık bir görüş beyan etmeyi amaçlamaktadır (Fasan vd., 2016; 6). Entegre raporun asıl amacı finansal sermaye sağlayan taraflara işletmenin zaman içinde nasıl değer yaratacağını açıklamaktır (Gençoğlu ve Aytaç, 2016:55; Kaya vd., 2016:88).

Entegre raporlama ile aşağıdaki amaçlara ulaşılması beklenmektedir (Y1lmaz vd, 2017:98):

- Sermaye sağlayıcılara finansal bilgiler ile daha kaliteli bilgi sağlamak,

- Kurumsal raporlamaya işletmenin değer yaratma süreçlerini etkileyen tüm faktörleri yansıtarak bütüncül bir bakışs sağlamak,

- Hesapverilebilirlik ve anlaşılabilirliği arttıracak tüm ilişkileri açıklamayı sağlamak,

- Karar verme noktasinda kisa, orta ve uzun vadede değer yaratma temelli tüm bilgileri birleştirebilmek.

\subsection{Entegre Rapor Hazırlama Ölçütleri}

Uluslararası Entegre Raporlama Konseyi (International Integrated Reporting Council- IIRC) tarafindan hazırlanan "Uluslararası Entegre Raporlama Çerçevesi" entegre raporlamanın düzenlenmesine yardımcı olmak maksadıyla Aralık 2013'de yayınlanmıştır. Değer yaratma potansiyeli, süreci ve bu süreçte kullanılan sermaye ögeleri Temel Kavramlar olarak tanımlanmıştır (Aracı ve Yüksel, 2017:392; Maniora, 2017:755). Entegre rapor, düzenlenmesinde esas alınan ve raporun oluşturulması sürecine yönelik bilgi sağlayan Kılavuz İlkeler ve sunulması gereken bilgileri birbirleriyle bağlantılı şekilde açıklayan İçerik Ögeleri'nden oluşmaktadır (Gençoğlu ve Aytaç, 2016:55). Uluslararası Entegre Raporlama Çerçevesi'nin bölümleri şu şekildedir (IIRC, 2013): Kılavuz ilkeler (stratejik odak ve geleceğe yönelim, bilgiler arası bağlantı, paydaşlarla ilişkiler, önemlilik, kısa ve öz olma, güvenilirlik ve tamlı, tutarlılık ve karşılaştırılabilirlik) ve içerik ögeleri (kurumsal genel görünüm ve diş çevre, kurumsal yönetim, iş modeli, riskler ve firsatlar, strateji ve kaynak aktarımı, performans, genel görünüm, hazırlık ve sunum temeli).

\subsubsection{Temel Kavramlar}

Temel kavramlar, entegre raporda yer alan bilgilerin temelini oluşturan ve anlamlandıran kavramlardır. Bu kavramlar, entegre raporda sunulan değer yaratma, bu değeri yaratırken etkilenen sermaye ögeleri ve değer yaratma sürecidir.

İşletmeler, kendileri ve ortakları için değer yaratabildiği gibi başkaları içinde değer yaratabilmektedir. İşletmelerin çoğu ortakları için sürdürülebilir karlılığı sağlamanın yanında istihdam oluşturmak, toplumun ihtiyaçlarını karşılayacak yenilikler üretmek gibi sosyal değerleri de dikkate almaktadır. İşletme ortakları ve potansiyel yatırımcılar öncelikle kendileri için yaratılan değerle ilgilenseler dahi, diğer yaratılan sosyal değerler de işletmenin değer yaratma yeteneğini etkilemektedir. Entegre raporlamada işletmenin yarattığı değer ile değer yaratma sürecini etkileyen faktörlerin sunulması esastır. 
Entegre raporlama ile yaratılan değerin daha kolay anlaşılması sağlanmaktadır. Değer yaratma işletmenin iş modeli vasıtasıyla gerçekleşir. Sermaye ögeleri ile girdilerin işletme faaliyetleri çerçevesinde çıktılara dönüştürülmesi neticesinde değer yaratılır (Aras ve Sarığlu, 2015: 51).

Sermaye ögeleri, işletme faaliyetlerinin gerçekleştirilmesinde kullanılan ve çerçevede altı başlıkta ifade edilen ögelerdir. $\mathrm{Bu}$ sermaye ögeleri, finansal sermaye, üretilmiş sermaye, fikri sermaye, insan sermayesi, sosyal ve ilişkisel sermaye ve doğal sermayedir.

Finansal sermaye, ortaklardan sağlanan özsermaye ve bankalardan veya diğer kişi veya kurumlardan sağlanan kaynaklar olarak ifade edilir.

Üretilmiş sermaye, kuruluş tarafından elde edinilmiş veya üretilmiş olan maddi varlıklardır (bina, ekipman, makine vb.) (Adams ve Simnett, 2011:296; Cochrane, 2006).

Fikri sermaye, işletmenin sahip olduğu her türlü marka, patent, teknik bilgi gibi maddi olmayan varlıklardır. Bu unsurlar rekabet gücünü arttırmaktadır (Stewart,1997). Entelektüel sermaye olarak da bilinen bu kavram, rekabet avantajı sağlamada işletmeye destek sağlayan işletme çalışanlarının bilgi ve tecrübelerinin toplamı olarak ifade edilebilir (Şamiloğlu, 2002:67).

İnsan sermayesi, işletmenin sahip olduğu insan gücünün yetenekleri, donanımları, motivasyonları şeklinde ifade etmek mümkündür (Küçükgergerli, 2017:41).

Sosyal ve ilişkisel sermaye, işletmenin paydaşlarıyla arasındaki ilişkiden ortaya çıkan sermaye unsurudur.

Doğal sermaye ise, yenilenebilir (rüzgar, güneş vb.) veya yenilemez (su, toprak vb.) kaynaklardan oluşur.

Değer yaratma süreci, işletmenin sağladığı girdileri işletmenin misyonu, vizyonu, dış çevre unsurları, kurumsal yönetim anlayışı, risk ve fırsatları, strateji ve kaynak aktarımı, performansı ile çıktılara dönüştürme serüveni olarak ifade edilebilir. Burada sayılan tüm unsurlar değer yaratma sürecinde aktif rol oynamaktadır.

\subsubsection{Entegre Raporlama Kilavuz İlkeleri}

Kılavuz ilkeler entegre rapor hazırlanırken yol gösterici nitelik taşımaktadır. Raporun düzenlenmesinde dikkat edilmesi gereken hususlar ilkeler halinde belirtilmiştir. $\mathrm{Bu}$ ilkelerin açıklanmasına aşağıda yer verilmiştir.

\section{Stratejik Odak ve Geleceğe Yönelim}

Entegre rapor, işletmenin stratejisini, kısa, orta ve uzun vadede değer yaratma kabiliyeti ile sermaye ögeleri arasındaki ilişkiyi açıklayıcı bilgi sunmalıdır (IIRC, 2013). Raporda işletmenin stratejileri ile değer yaratma kabiliyeti arasındaki etkileşim ortaya konmalıdır (Aydın, 2015:31). İşletme stratejileri, kaynakların kullanımı, işletmenin maruz kaldığ 1 ya da kalacağı risk ve firsatlar, gelecek yönelimi, performanslarının karşılaştırılması, amaçlarının vadeler arasındaki uyumu, sermaye ögelerinin mevcut ve gelecekteki durumu gibi konular entegre raporlama yapılırken rapora dahil edilmelidir (Yüksel, 2017:76).

\section{Bilgiler Arası Băglantı}

İşletmenin değer yaratma sürecini etkileyen tüm unsurlar ve bu unsurların birbirleriyle olan etkileşimleri raporda yer almalıdır (Aydın, 2015:31). Raporda sunulacak bilgiler birbirleriyle olan ilişkileri göz önüne alınarak sunulmalıdır. Bilgiler arasındaki ilişkiyi yansıtabilmek entegre düşünce ile mümkün olmaktadır. İşletmenin farklı raporlarda yer alan bilgilerinin birbiriyle entegrasyonu sağlanarak bütüncül bir yaklaşımla ele alınması entegre düşüncenin varlığını gösterir (Yüksel, 2017:77). İşletme tarafindan üretilen bilgiler arasındaki bağlantının sağlanması ile işletme hakkında bilgi sahibi olmak isteyenler işletmeyi bir bütün olarak değerlendirebilecektir.

\section{Paydaşlarla İlişkiler}

Entegre raporda, işletmenin paydaşları ile ilişkilerinin kalitesi ve etkinliğine yönelik bilgi sunulması ve paydaşların beklentilerine ne şekilde ve ölçüde cevap verildiği açıkça belirtilmelidir (Yılmaz vd., 2017:104). İşletmenin aldığı kararlarda paydaşların etkisi, karar vermeye katılımları ve işletmenin bu konulardaki tutumu raporlarda açıklanmalıdır. $\mathrm{Bu}$ bilgiler işletmenin paydaşlarına verdiği değeri ifade etmekle birlikte paydaşları işletmenin ayrılmaz bir parçası olarak gösterecektir. Bu durum paydaşların işletmeye olan sadakatini de artıracaktır.

\section{Önemlilik}

İşletmede üretilen bilgilere önemlilik düzeylerine göre raporda yer verilmesi gerekir. Önemlilikten kasıt, işletmenin kısa, orta ve uzun vadede değer yaratma kabiliyetine etki eden tüm konuların raporda yer almasıdır (IIRC, 2013). Burada hangi konuların önemli olup olmadığına ilişkin olarak önemlilik derecesinin belirlenmesi gerekmektedir. İşletmenin değer yaratma sürecini etkileyecek, önlem alınmadığı durumlarda ya da çözüm üretilmediği hallerde işletmenin geleceğine ilişkin daha kötü sonuçlar doğuracağı muhtemel olan konular önemli olarak ifade edilmektedir (Yüksel, 2017:78). Aslında bu kavram geleneksel önemlilik kavramı ile aynı şeyleri ifade etmektedir. Karar vericilerin kararını etkileyebilecek bir bilgi önemlidir ve raporlarda mutlaka yer almalıdır.

\section{Kısa ve Öz Olma}

Entegre raporda yer alacak bilgilerin gereksiz olmamasına ve açıklanacak bilgilerin özet bir şekilde sunulmasına özen gösterilmelidir (Aydın, 2015:31). Entegre raporun diğer raporlardan farklı olarak önemli bilgileri kısa veöz bir şekilde sunması beklenmektedir. Bu kısa ve özlük rapordan beklenen açıklamaların yapılmaması olarak anlaşılmamalıdır. Raporun ihtiyacı karşılayacak düzeyde bilgiyi anlaşılabilir şekilde özetlemesi olarak düşünülmelidir. Raporun kısa ve öz olması ile elde edilmek istenen bilgilere kolay ve hızlı bir şekilde ulaşılabilecektir.

\section{Güvenilirlik ve Tamlık}

Entegre raporda yer alacak bilginin güvenilir olması gerekir. Güvenilir olmayan bilgi önemli dahi olsa raporda yer almayabilir. Bu durum raporun güvenilirliğini ortadan kaldırmaz (Yüksel, 2017:79). Aynı şekilde raporda yer alan bilgilerin işletmenin tüm yönlerini kapsaması gerekmektedir. İşletmenin pozitif ve negatif yönleri eksiksiz bir şekilde sunulmalıdır. $\mathrm{Bu}$ durum işletme 
hakkında bilgi sahibi olmak isteyen tarafların kararlarını etkilememesi açısından oldukça önemlidir. Tamlıktan kasıt var olan tüm bilgileri olduğu gibi rapora yansıtmaktır. Burada tabiki önemlilik hususu dikkate alınarak raporların tüm bilgileri kapsaması anlaşılmalıdır. Aksi takdirde raporların gereksiz bilgi tekrarına düşmesi söz konusu olabilir.

\section{Tutarlılık ve Karşılaştırılabilirlik}

Tipk1 finansal raporlamada olduğu gibi entegre raporlamada da sunulan bilgilerin tutarlı ve karşılaştırılabilir olması gerekmektedir. İşletmenin sunduğu bilgilerin karşılaştırılabilir olması için birbirini izleyen dönemlerde sunulan bilgilere ilişkin kriterlerin değişikliğe uğramaması gerekmektedir. Aksi durumlarda karşılaştırma yapma imkanı olmayacaktır. Yine bu durum tutarlılık ile de yakından ilgilidir. Uygulanan politikaların, ilke ve kuralların dönemler itibariyle değişmeden uygulanması hem tutarlılığı hem de karşılaştırılabilirliği sağlamaktadır. Herhangi bir değişiklik söz konusu olması halinde de bu durumun nedenleri ve raporlara etkileri ile birlikte açıklanması gerekmektedir.

\subsubsection{Entegre Raporlama İçerik Ögeleri}

Entegre raporlama, birbiriyle bağlantılı sekiz içerik ögesine sahiptir. Bu ögeler;
a) Kurumsal genel görünüm ve diş çevre,
b) Kurumsal yönetim,
c) İş modeli,
d) Riskler ve firsatlar,
e) Strateji ve kaynak aktarımı,
f) Performans,
g) Genel görünüm,
h) Hazırlık ve sunum temelidir.

$\mathrm{Bu}$ ögeler raporda yer alması gereken konuları birbiri ile bağlantılı şekilde açıklamayı hedefler. Bu ögelere aşağıda başlıklar halinde değinilmiştir.

\section{Kurumsal Genel Görünüm ve Dış Çevre}

Entegre rapor, işletmenin kurumsal yapısı, misyon ve vizyonu, kurum kültürü, etik değerleri, mülkiyet ve faaliyet yapısı, faaliyet gösterdiği alan ve pazarları, rekabet gücü ve pazar içindeki konumu, değer zincirindeki konumu, önceki dönemlerde yaşanan önemli değişiklikleri, dış çevreyi ve işletmeyi etkileyen önemli faktörleri açıklar (IIRC, 2013).

Misyon, işletmeye istikamet vermek ve anlamlandırmak maksadiyla belirlenen ve işletmeyi diğerlerinden ayrıştırmaya yarayan görev veya amaç şeklinde tanımlanabilir (Dinçer, 1991:55). Yani işletmenin varoluş amacını ifade eder. Entegre raporda bu ifade açıkça belirtilmelidir. Diğer bir kavram olan vizyon ise işletmenin gelecekte olmak istediği yer olarak ifade edilir. Vizyon kavramı da entegre raporda yeralması gereken ifadelerdendir. Bu iki kavram işletme hakkında temel bilgi sağlaması nedeniyle önem arz etmektedir. Entegre rapor, bir işletmenin misyonunu ve amacını açıklayabilmeli, bu misyonauyulmasını sağlamak için kurumsal yönetim ve izleme yöntemlerini özetlemeli ve finansal performans üzerindeki etkisini ölçebilme yeteneğini göstermelidir (Smith, 2015:96).

İşletme içinde yaratılan değerler, işletme faaliyetlerinin yapısı, faaliyet gösterilen alanlar ile faaliyette bulunulan pazarlar raporda belirtilmelidir. $\mathrm{Bu}$ bilgiler işletme hakkında genel bilgi sağlamanın ötesinde işletmenin kurumsal yapısını tarif etmektedir. İşletmenin hangi konulara değer verdiği, faaliyetlerini hangi alanlarda yoğunlaştırdığı ve hangi pazarlarda faaliyet gösterdiği bilgileri işletmenin gelecek perspektifini de ortaya koymaktadır.

İşletmenin dış çevre ile olan etkileşimi de raporda yer almalıdır. İşletmenin değer yaratma sürecine etki eden dış faktörlerin işletmeyi etkileme durumları ve gelecekte ortaya çıkabilecek faktörlerin açıklanması açısından önemlidir.

\section{Kurumsal Yönetim}

Kurumsal yönetim, işletmenin ortaklarıyla ve toplumun tüm kesimiyle ilişkilerini düzenleyen sistemler bütünü olarak tanımlanabilir (Aysan, 2007:18). Entegre raporda, kurumsal yönetimin yapısı, kurumsal yönetim sorumlularının kabiliyetleri, risk yönetimine yönelik davranışları, kurumsal yönetim konusunda yapılan çalışmalara yer verilmelidir (Yüksel, 2017:81). Ek olarak, kurumsal yönetim uygulamalarının yasal sınırı aşıp aşmadığı, kısa, orta ve uzun vadede değer yaratma ile ücret teşvik ve uygulamalar arasındaki ilişki, kurumsal yönetim sorumlularının yenilik teşvikine ilişkin tutumları gibi konulara da raporda yer verilmelidir (Aydın, 2015:33).

Kurumsal yönetim uygulamalarının entegre raporda yer alması sonucunda, kurumsal süreçlerde izlenen politikaların ve politika oluşturma süreçlerinin sermaye ögeleri ile etkileşiminin yarattığı sonuçlar açıklanmış olmaktadır. Bu durum kurumsal yönetim sorumlularının değer yaratma sürecinde uygulanan kurumsal yönetim politikalarına yönelik tutumlarını ortaya koymaya destek sağlamaktadır.

\section{İș Modeli}

İşletme faaliyetlerini ve değer yaratma süreçlerini anlamamızda temel bir kavram olan iş modeli, bir işletmenin örgütsel ve finansal mimarisini bünyesinde barındırır ve firmaların kaynak ve yeteneklerini değere dönüştürme yolarını ifade eder (Melloni vd., 2016:296). İş modeli, işletmenin sermaye ögelerini kullanarak çıktılara dönüştürme sürecinde gerçekleştirilen faaliyetler bütünü olarak da tanımlanabilir. İşletmenin iş modelinin entegre raporda sunulması gerekmektedir. İş modelinin sunulması ile işletmenin değer yaratma sürecindesermeye unsurları ile girdi olarak kullanması ve bu girdileri gerçekleştirilen faaliyetlerle çıktılara dönüştürmesi ve neticede ortaya çıkan sonuçların değerlendirilmesi sağlanmaktadır.

İş modeli açıklanırken girdi, işletme faaliyetleri, çıktı ve sonuçlar kavramları kullanılmaktadır. Bu kavramlar iş modelinin unsurları olarak ifade edilebilir. Girdi olarak ifade edilen, sağlanan sermaye ögeleridir. İşletmefaaliyetleri, işletmenin müşteriler tarafindan talep edilen mal veya hizmetleri üretmek için gerçekleştirdiği faaliyetlerin tümüdür. Çıktı isegirdilerin işletme faaliyetleri kullanılarak üretilen mal veya hizmetler olarak ifade edilir. Sermaye ögelerinde iş faaliyetleri neticesinde ortaya çıkan değişimler ya da iş faaliyetlerinin sermaye ögelerinde 
meydana getirdiği etkiler ise sonuç olarak açıklanır (Yüksel, 2017:82).

İş modeli, işletmenin sağladığı kaynakları kullanarak üretim öncesi ve sonrası süreçlerini gözeterek müşteri ihtiyaçları doğrultusunda mal ve hizmet üretme serüvenidir. Bu model aynı zamanda değer yaratma sürecinin temeli olarak karşımıza çıkmaktadır.

\section{Riskler ve Firsatlar}

Risk ve firsatlar, işletmenin kısa, orta ve uzun vadede karşılaşacağı durumlardır. Bunlar, işletmenin değer yaratma kabiliyetini etkileyen önemli kavramlardır. İşletmenin karşılaşacağı iç ve dış riskleri belirlemesi ve bunlara yönelik olarak etkin bir yönetim politikası oluşturması gerekmektedir. Ortaya çıkabilecek risk ve firsatların, bunların olası etkilerinin ve bu risklere karşı alınacak önlemlerin neler olduğu entegre rapora dahil edilmesi gereken önemli konulardır. İşletmenin maruz kalacağı risklere karşı nasıl tepki vereceği risklerin gerçekleşmesi halinde nasıl bir yönetim stratejisi izleneceği de merak uyandırmaktadır. Tüm bu nedenler göz önüne alındığında işletmenin bu konularda entegre raporda açıklama yapması hayati öneme sahiptir.

İşletme tarafından risk ve firsatların belirlenmesi, bunlara yönelik politika geliştirmede işletmeye karar desteği sağlar. $\mathrm{Bu}$ karar desteği işletmenin rekabet gücüne olumlu etki eder (Aydın, 2015:34).

\section{Strateji ve Kaynak Aktarımı}

İşletmenin hedeflerinin ne olduğu ve bu hedeflere ulaşmak için izlenen yolların entegre raporda yer alması gerekir (Yılmaz vd. 2017:105). İşletmenin kısa, orta ve uzun vadede gerçekleştirmek istediği hedeflerinin ve bu hedefleri gerçekleştirmek için uygulayacağı stratejiler ve bu stratejileri uygulamada kullanacağı kaynaklarının neler olduğu raporda yer almalıdır. Belirlenen hedeflere ulaşma derecesi, izlenen politikaların etkinliği ve sonuçları da aynı şekilde raporda paylaşılmalıdır. Belirlenen hedeflerin ve bu hedefleri gerçekleştirmede izlenen stratejilerin ne şekilde değerlendirileceği, bunlara ilişkin kriterlerin de açıkça belirtilmesi gerekmektedir. Hedeflerin belirlenmesi, strateji geliştirilmesi ve kaynak tahsisi konularının işletmenin değer yaratma kabiliyeti ile etkileşimi konularına da raporda yer verilmelidir.

\section{Performans}

İşletmenin hedefleri gerçekleştirmede gösterdiği başarı durumu ve bu başarının sermaye ögelerine olan etkisi nitel ve nicel olarak raporda yer almalıdır. Performansın hem dönem içerisinde hem de önceki dönemlerle karşılaştırmalı olarak sunulması gerekir. Finansal performansın yanında finansal olmayan performans sonuçları da bir arada sunulmalıdır. İşletmenin değer yaratma süreçlerinde gerçekleştirdiği performans sonuçları belirlenen temel göstergeler yardımıyla açıklanmalıdır (Yılmaz vd. 2017:105; Aydın, 2015:34; Yüksel, 2017:84: IIRC, 2013).

Finansal ve finansal olmayan performans sonuçlarının bir arada sunulması ile işletmenin bir bütün olarak değerlendirilmesi mümkün olmaktadır. $\mathrm{Bu}$ durum işletmelerin finansal performansları dikkate alınarak yapılan değerlendirmeler sonucunda ortaya çıkan hataları minimuma indirecektir. Finansal performansa etki eden finansal olmayan yani sosyal ve çevresel performans sonuçlarının da dikkate alınması ile daha faydalı ve daha sağlıklı değerlendirme imkanı sağlanmış olacaktır.

\section{Genel Görünüm}

İşletmenin geleceğe yönelik beklenti ve gelecekte karşılaşabileceği durumlar hakkında da raporda açıklamalara yer verilmelidir. Gelecekte ortaya çıkması muhtemel olan durumların belirlenmesi, bunlara yönelik tedbirlerin neler olacağı ve işletme performansına etkileri konularında açıklamaların raporda yer almasına özen gösterilmelidir. İşletmenin karşılaşabileceği tüm olaylara yönelik alınacak önlemler ve izlenecek politikalar raporda sunulmalidir.

\section{Hazırlı ve Sunum Temeli}

İşletme performansına ilişskin bilgilerin hangi kıstaslar doğrultusunda rapora dahil edildiğine dair ifadeler yer almalıdır. Raporda, entegre raporlama sürecine ilişkin olarak özet bilgiler bulunmalıdır. Önemlilik süreci, raporlama sınırlarının nasıl belirlendiği, finansal sonuçları açıklamak için belirlenen yöntemlerin neler olduğu gibi konular bu içerik ögesi içerinde sunulmalıdır (IIRC,2013).

Hazırlık ve sunum temeli olarak ifade edilen içerik ögesi, rapor hazırlanırken dikkate alınan konular hakkında açıklamaları ifade eder. Rapor oluşturma sürecinde izlenen politikalar, rapora dahil edilecek hususları belirleme kriterleri, raporda sunulan bilgilerin sınırlarının neler olduğu gibi bilgilere yer verilir. Bu içerik ögesi bir nevi raporun çerçevesini çizmektedir.

\subsection{Entegre Raporlamanın Yararları}

Entegre raporlamanın sağlayacağı yararları işletmeler, yatırımcılar ve diğer paydaşlar açısından aşağıdaki şekilde ifade etmek mümkündür (http://www.entegreraporlamatr.org; Aras ve Sarığlu 2015:45; Hurghis, 2017: 84; Kanzer 2010, 46-47; Ivanovna, 2016):

- Finansal veriler ile finansal olmayan verilerin bir arada sunulması ile kurumsal stratejilerin entegre bakış açısıyla geliştirilmesi sağlanır.

- Farklı faaliyetlerin bir arada birbiriyle bağlantılı olarak sunulması ile faaliyetlerin kolay bir şekilde takip edilmesi sağlanır ve bu da karar alma süreçlerini hizlandirır.

- İşletmenin ortaya çıkardığı değer göz önüne alınarak strateji geliştirme, kaynakların etkin kullanımını değer yaratma süreci ile uyumlaştırır.

- Uzun vadeli plan yapma imkanı sağlar.

- Hem ekonomiklik hem de sürdürülebilirlik konusunda daha etkin risk analizine imkan sağlar.

- Bilgi entegrasyonu ile analiz maliyetlerinde tasarruf sağlar.

- Departmanlar arası işbirliğini artırır.

- İnovasyon düşüncesini geliştirir.

- Paydaşların süreçlere katılımını sağlayarak beklentilerine cevap verebilme imkanlarını geliştirir.

- Çalışanların işletme süreçlerine dahil edilmesini sağlayarak, motivasyonu ve aidiyet duygusunu geliştirir ve çalışanların üretilen değerin bir parçası olduğu vurgulanır. 
- İşletmenin tüm yönlerinin açık bir şekilde paylaşılması ile işletmeye olan güven, saygınlık ve marka değeri artar.

- Kaliteli raporlama ve şeffaflığın sağlanması ile yatırımcıların güveni sağlanır ve finansman erişimi kolaylaşır.

- İşletmenin rekabet gücünü arttırır.

- Finansal risklerin yanında finansal olmayan risklere karşı işletmenin yönetim anlayışı hakkında bilgi sunar.

- Kısa, orta ve uzun vadede işletmenin değer yaratma potansiyeli hakkında bilgi sağlar.

- Entegre raporlama işletme hakkındaki tüm bilgileri tek bir çatıda toplayarak tüm bilgilere tek elden ulaşılmasını sağlar.

- Yatırımcıların işletme hakkında öğrenmek istediği bilgilerin raporda yer almasını sağlar.

- Yatırımcılar açısından standart, güvenilir ve karşılaştırılabilir bilgi sunar.

- Yatırım kararı verirken işletmeleri daha detaylı analiz etme imkanı sağlar.

- Tüm paydaşların daha iyi tanınmasını sağlayarak, paydaşlarla olan ilişkileri güçlendirir.

- İşletmenin tedarik zinciri ile olan ilişkisini daha anlaşılır bir şekilde açıklar ve değer yaratma sürecine katkısını gösterir.

- İşletmenin kendini daha iyi anlatması ile genç işgücü sahiplerinin işletmeyi tanımasına imkan sağlar.

- Tüketicilerle sürdürülebilirlik konusunda daha yakın ilişkiler sağlar.

- Sosyal ve çevresel konularda sorumluluk duygusunu çalışanları ve toplumla paylaşmasına imkan sağlar.

\subsection{Dünya'da Entegre Raporlama}

Entegre Raporlama çoğu ülkede gönüllü bir uygulamadır (Sierra-Garcia vd., 2015:287). Entegre raporlamanın gelişmesine öncülük eden ülke konumunda bulunan Güney Afrika, 2010 yılında Johannesburg Borsası'na kote olan tüm işletmelerin entegre rapor yayımlamasını zorunlu hale getirmiştir. Bu durum, Dünya genelinde dikkatlerin entegre raporlamaya yöneltilmesine neden olmuştur. Pek çok ülke zorunlu tutmasa da entegre raporlamayı teşvik etmiştir. Güney Afrika'yı Hollanda, Brezilya ve Avustralya izlemektedir. Avrupa Birliği'nde büyük ölçekli işletmelerin finansal bilgilerinin yanında finansal olmayan bilgilerinin de sunulmasına yönelik bir yaklaşım 2014 yılında kabul edilmiştir. $\mathrm{Bu}$ uygulama, tam olarak entegre raporlama olarak ifade edilmese de Danimarka, Portekiz, Fransa'da finansal olmayan bilgilerin açıklanması ile birlikte entegre raporlamaya doğru bir yönelim gerçekleştirmiştir. Ayrıca Finlandiya, İsviçre, İspanya, ABD, İsveç, Kanada, Almanya ve İngiltere gibi ülkeler de entegre raporlama yapılanülkeler arasında yer almaktadır (Y1lmaz vd., 2017:106).

Entegre raporlama konusunda Dünya genelinde çalışmalar giderek hızlanmakta ve entegre raporlama yapan işletme ve uygulama yönünde karar alan ülke sayısı günden güne artmaktadır.Bu durum, işletmelerin ve ülkelerin entegre raporlamanın gerekliliği konusunda fikir birliğine vardığının bir göstergesidir. 2020'li yıllarda raporlamanın tümüyle entegre raporlamaya yöneleceğini ifade eden akademisyenler de bulunmaktadır.

\subsection{Türkiye'de Entegre Raporlama}

Türkiye'de entegre raporlama konusunda ilk çalışmalar, 2011 yilında Türkiye Kurumsal Yönetim Derneği (TKYD) ve Sürdürülebilir Kalkınma Derneği (SKD) tarafından kurulan çalışma grubu ile başlamıştır. Entegre Raporlama Türkiye Ağı'nın kurulmasına kadar geçen sürede TKYD entegre raporlama konusunda koordinasyonu sağlamıştır. 2013 yılında Garanti Bankası ile Çimsa entegre raporlama hazırlamak için IIRC'ye katılan ilk Türk işletmeleri olmuştur. 2015 yılında ARGE Danışmanlık ve Argüden Yönetişim Akademisi tarafından Türkiye'nin G20 Başkanlığg'nda entegre raporlama G20 liderlerine öneri olarak sunulmuştur (http://www.entegreraporlamatr.org).

Entegre raporlama konusunda Türkiye'de yayınlanan ilk rapor, Argüden Yönetişim Akademisi tarafından 2015 yılında yayınlanmıştır. Aynı kurum 2016 yılında da entegre rapor yayınlamıștır. Diğer bir rapor da Türkiye Sınai Kalınma Bankası tarafından 2016 yılında yayınlanmıştır (Yüksel, 2017:140-141). Entegre raporlama konusunda ilk raporlar olması açısından bu raporlar önem arz etmektedir. Çimsa 2016 yılında entegre raporlama yayınlayan ilk reel sektör işletmesi olmuştur. Garanti Bankası'nın çalışmaları ise devam etmektedir. Ancak entegre raporlama yapan işletme sayısının oldukça az olduğu görülmektedir. İlerleyen süreçte daha çok işletmenin entegre raporlama yapması beklenmektedir.

\subsection{Entegre Raporlamanın Diğer Raporlama Türleri İle Karşılaştırılması}

Entegre raporlama ile diğer raporlama türleri arasında önemli farklılıklar bulunmaktadır. Bu farklılıklar entegre raporlamanın getirdiği yenilikler olarak da düşünülebilir. Entegre raporlama diğer raporlama türlerinden izler taşısa da kendine münhasır özellikleri bulunmaktadır.

Mevcut kurumsal raporlamalar, strateji, kurumsal yönetim, faaliyetler ile finansal ve finansal olmayan performans arasındaki önemli ilişkiyi yansıtmamaktadır (IIRC, 2011). Oysa entegre raporlama, hem finansal hem de finansal olmayan performans sonuçlarını, strateji, kurumsal yönetim ve işletme faaliyetleri ile bağdaştırarak bir arada sunmaktadır.

Sürdürülebilirlik raporlaması, karşılaşılan riskler ve fırsatlar konusunda şeffaflığı artırmak amacıyla oluşturulurken; entegre raporlamaözünde paydaşların bir işletmenin strateji, yönetim, performans ve beklentilerinin açıklanması ile daha iyi bir iletişim sağlaması amacıyla tasarlanmıştır (Ştefanescu vd., 2016:543).

Entegre raporlar finansal ve finansal olmayan bilgileri içerdikleri için geleneksel kurumsal raporlara göre daha kapsamlıdır (Barth vd., 2017:5). Kapsamın geniş olması işletmeyi etkileyen tüm faktörlerin ve bu faktörlere ilişkin bilgilerin raporda sunulması ile ilgilidir.

Geleneksel finansal raporlama temel olarak finansal bilgi sunmaya hizmet ederken, entegre raporlar içe dönük karar vermeyi etkileme gücüne sahiptir (Eccles ve Serafeim, 2015). Geleneksel raporlama bir zaruri açıklama olarak düşünüldüğünden sadece bilgi verme amacı taşımaktadır. Ancak entegre raporlama geniş perspektifle işletmenin karar alma mekanizmasına destek sağlamaktadır. 
Entegre raporlama nicel bilgiler ile ileriye dönük odaklanmay1 gerektirir (Stacchezzini vd., 2016:103). Finansal raporlama ise geçmişe dönük bilgilerden hareketle düzenlenmektedir. Geleceğe yönelik gerçekçi bir bakış açısı sunmamaktadir.

Finansal raporlama, sadece nicel bilgileri dikkate alarak finansal performansı yansitmaktadır. Entegre raporlama, finansal bilgilerin yanı sosyal, çevresel, kurumsal performansı ve bunların birbirlerine olan etkilerine de yer vermektedir. $\mathrm{Bu}$ da sonuçta işletmenin geleceğe dönük kararlar almasına katkı sunmaktadır.

\section{Araştırma}

\subsection{Araştırmanın Amacı}

$\mathrm{Bu}$ çalışmanın amacı entegre raporlama yapan işletmelerin yayınladıkları raporların entegre raporlama içerik ögeleri açısından incelenmesidir. Bu amaç doğrultusunda 2016 yılı Fortune Global 500 listesinde yer alan 50 işletmenin entegre raporları incelenmiştir. Raporların içerik ögelerini ne ölçüde yansıttığı araştırılmıştır. Raporlarda açıklanan bilgilerin entegre raporlama içerik ögeleri kapsamında hangi konuları açıkladığına yönelik olarak anahtar kelime bazında incelemeler yapılmıştır. Nitel araştırma yöntemlerinden içerik analizi yöntemi uygulanarak gerçekleştirilen çalışmada en çok tekrarlanan sözcükler de belirlenerek açıklanmıştır.

\subsection{Araştırmanın Evreni ve Örneklem}

Araştırmanın evreni olarak entegre raporlama yapan işletmeler seçilmiştir. Ancak bu işletmelerin raporlarına ulaşmak ve araştırmaya dahil etmek hem zor olacağından hem de çalışma süresini uzatacağından örnekleme yoluna gidilmiştir. 2016 yılı Fortune Global 500 listesinde yer alan işletmelerin entegre raporları araştırılmış ve entegre rapor yayınlayan işletmeler arasından tesadüfi olarak 50 işletmenin 2016 yılında yayınladıkları entegre raporlar araştırmaya dahil edilmiştir.

\subsection{Araştırmanın Yöntemi}

Araştırmada nitel araştırma yöntemlerinden içerik analizi yöntemi uygulanmıştır. İşletmelerin yayınladıkları entegre raporlar içerik ögeleri yönünden içerik analizine tabi tutulmuştur. $\mathrm{Bu}$ amaçla ilk önce içerik ögelerine ilişkin anahtar kelimeler literatürden yararlanılarak tespit edilmiştir. Daha sonra her bir içerik ögesinin alt konularına ilişkin anahtar kelimeler belirlenerek tümevarım yaklaşımı ile analiz gerçekleştirilmiştir. Herbir raporun özelinde ve 50 raporun geneline ilişkin olarak kelime sıklıkları da incelenmiştir.

Entegre raporlama içerik ögelerinin raporlarda açılanma düzeylerine yönelik olarak gerçekleştirilen çalışmada, içerik ögelerinin her birine ilişkin belirlenen anahtar kelimeler vasıtasıyla açıklanan konuların belirlenmesine çalışılmıştır. Anahtar kelimelerin raporlarda ne sıklıkla geçtikleri ve raporda yer alan kelimelerin ne anlam ifade ettiğinden hareketle açıklanan bilgilerin analiz edilmesi sağlanmıştır. Nitel bir çalışma olması nedeniyle anahtar kelimeler ile açıklanan bilgilerin ilişkilendirilmesi hedeflenmiştir. Hangi kelimenin hangi raporda ne sıklıkla geçtiği ve sonuçta bu kelimenin içinde yer aldığ 1 cümle ya da paragrafta ne tür bir anlam ifade ettiğine yönelik çalışma stratejisi belirlenmiștir. Calıșmada NVivo paket programı kullanılarak analiz gerçekleştirilmiştir.

\subsection{Araştırmanın Sinırlılıkları}

Analize tabi tutulan işletme sayısının 50 olması çalışmanın sinırlılığ 1 olarak ifade edilebilir. Entegre raporlama yapan işletme sayısı günden güne artış göstermesine karşın, çalışmanın yapıldığı dönemde Türkiye'de yeterli sayıda raporlama yapan işletme bulunmamaktadır. $\mathrm{Bu}$ durum araştırma kapsamına dünya genelindeki işletmelerin dahil edilmesine yol açmıştır. Dünya genelinde entegre raporlama yapan işletme sayısının da çok olması nedeniyle örnekleme yoluna gidilmiş ve 50işletme seçilmişstir.

\subsection{Araştırma Sonuçları}

Araştırma amacı doğrultusunda 50 işletmeye ait entegre raporlar incelenmiştir. Araştırmaya dahil edilen şirketler ve bunların faaliyet gösterdiği sektörler ile yayınladıkları raporların sayfa sayısına ilişkin bilgiler aşağıdaki tabloda verilmiştir.

Tablo 1. Araştırmaya Dahil Edilen İşletme Bilgileri

\begin{tabular}{|c|c|c|c|}
\hline Kod & İşletme Adı & Sektör & $\begin{array}{l}\text { Rapor } \\
\text { Sayfa } \\
\text { Sayısı }\end{array}$ \\
\hline Y01 & $\begin{array}{l}\text { Lloyds Banking } \\
\text { Group }\end{array}$ & Finans & 306 \\
\hline Y02 & National Grid & Enerji & 213 \\
\hline Y03 & Achmea & Sigortacilik & 326 \\
\hline Y04 & Aegon & Sigortacilik & 386 \\
\hline Y05 & Generali Group & Sigortacilik & 98 \\
\hline Y06 & $\begin{array}{l}\text { Tokio Marine } \\
\text { Group }\end{array}$ & Sigortacilik & 162 \\
\hline Y07 & ITOCHU & Ticaret & 98 \\
\hline Y08 & ArcelorMittal & Maden & 222 \\
\hline Y09 & $\begin{array}{l}\text { ASTRA } \\
\text { ZENECA }\end{array}$ & İlaç & 248 \\
\hline Y10 & AXA & Sigortacıllik & 102 \\
\hline Y11 & BAE SYSTEMS & $\begin{array}{l}\text { Havacilık ve } \\
\text { Savunma Sanayi }\end{array}$ & 192 \\
\hline Y12 & Barclays & Finans & 94 \\
\hline Y13 & BASF & Kimya & 260 \\
\hline Y14 & BAYER & İlaç & 344 \\
\hline Y15 & BHPBILLITON & Maden & 296 \\
\hline Y16 & $\mathrm{BP}$ & Petrol & 294 \\
\hline Y17 & $\begin{array}{l}\text { CHUBU Electric } \\
\text { Company }\end{array}$ & Enerji & 122 \\
\hline
\end{tabular}




\begin{tabular}{|c|c|c|c|}
\hline Y18 & Coca Cola & Gida & 216 \\
\hline Y19 & Enel & Enerji & 457 \\
\hline Y20 & Eni & Enerji & 95 \\
\hline Y21 & Fujitsu & Teknoloji & 86 \\
\hline Y22 & $\begin{array}{l}\text { GAS } \\
\text { NATURAL }\end{array}$ & Enerji & 428 \\
\hline Y23 & General Electric & Teknoloji & 68 \\
\hline Y24 & Hitachi & Teknoloji & 52 \\
\hline Y25 & IBERDROLA & Enerji & 100 \\
\hline Y26 & Deutsche Bahn & Demiryolları & 294 \\
\hline Y27 & Inditex & Tekstil & 356 \\
\hline Y28 & ING group & Finans & 459 \\
\hline Y29 & Sumitomo Riko & Sanayi & 44 \\
\hline Y30 & KDDI & Telekomünikasyon & 138 \\
\hline Y31 & $\begin{array}{l}\text { Mitsubishi } \\
\text { Heavy Industries }\end{array}$ & Sanayi & 58 \\
\hline Y32 & $\begin{array}{l}\text { Mitsubishi } \\
\text { Corparation }\end{array}$ & Ticaret & 60 \\
\hline Y33 & MS\&AD & Sigortacıllk & 94 \\
\hline Y34 & NEC & Teknoloji & 36 \\
\hline Y35 & Nippon & Telekomünikasyon & 62 \\
\hline Y36 & Novartis & İlaç & 274 \\
\hline Y37 & Orange & Telekomünikasyon & 98 \\
\hline Y38 & Panasonic & Teknoloji & 76 \\
\hline Y39 & Prudential & Finans & 232 \\
\hline Y40 & RANDSTAD & Danışmanlık & 188 \\
\hline Y41 & Rosneft & Enerji & 171 \\
\hline Y42 & SAP & Yazılım & 279 \\
\hline Y43 & $\begin{array}{l}\text { SOMPO } \\
\text { HOLDINGS }\end{array}$ & Sigortacılık & 180 \\
\hline Y44 & Telefonica & Telekomünikasyon & 201 \\
\hline Y45 & Toshiba & Teknoloji & 90 \\
\hline Y46 & UBS & Finans & 78 \\
\hline Y47 & Unilever & Gıda ve Tüketim & 185 \\
\hline Y48 & UNIPOL & Sigortacılık & 126 \\
\hline
\end{tabular}

\begin{tabular}{llll}
\hline Y49 & Vodafone & Telekomünikasyon & 208 \\
Y50 & WHL & Perakendecilik & 79 \\
Toplam & & & \\
Sayfa Sayısı & $\mathbf{9 3 3 1}$ & &
\end{tabular}

Yukarıdaki tablo incelendiğinde araştırmaya dahil edilen şirketlerin genel olarak, sigortacılık, enerji, teknoloji, finans, telekomünikasyon gibi sektörlerde faaliyet gösterdiği görülmektedir. Yayınlanan raporların sayfa sayıları birbirinden oldukça farklıdır. En az sayfa sayısına sahip olan şirket NEC (36) olurken, en fazla sayfa sayısında sahip şirket ING Group (459)'tur.

\subsection{1. İçerik Ögelerinin Açıklanma Durumları}

İçerik ögelerinin açıklanma durumları her bir içerik ögesi için belirlenen alt başlıklar ve kelimelerin raporlarda ne sıklıkla geçmesi ile belirlenmiştir. Toplam olarak açıklanma düzeyleri aşağıdaki tabloda yer almaktadır.

\section{Tablo 2. İçerik Ögelerinin Açıklanma Durumlarına İlişkin Değerlendirme}

\begin{tabular}{ll}
\hline Bölüm & Toplam Atıf Sayısı \\
Kurumsal Genel Görünüm ve Dış Çevre & 31335 \\
Kurumsal Yönetim & 11798 \\
İş Modeli & 6096 \\
Riskler ve Fursatlar & 18938 \\
Strateji ve Kaynak Aktarımı & 8350 \\
Performans & 11079 \\
Genel Görünüş & 8631 \\
Hazırlık ve Sunum Temeli & 28045 \\
\hline
\end{tabular}

Tablo 2 incelendiğinde, en çok atıfın (f $=31335$ ) "Kurumsal Genel Görünüm ve Diş Çevre" içeriğinde yapıldığ 1 görülmektedir. Bu içeriği 25768 atıfla "Hazırlık ve Sunum Temeli" ile 18938 atıfla "Riskler ve Firsatlar" takip etmektedir. En az atıf, (f=6096) "İs Modeli”, 8350 atıfla "Strateji ve Kaynak Aktarımı" ile 8631 atıfla "Genel Görünüş" ögelerine aittir. Raporlarda "Kurumsal Görünüm ve Dış Çevre", "Hazırlık ve Sunum Temeli" ve "Riskler ve Firsatlar" konularına diğer konulara göre daha fazla yer verildiği görülmektedir. "İş Modeli", "Strateji ve Kaynak Aktarımı" ve "Genel Görünüş" konularına ise daha az yer verildiği söylenebilir. Ancak iş modeli konusunda yapılan açıklamaların genelde şekilsel olmasını göz önünde bulundurmakta fayda bulunmaktadır.

İçerik ögeleri yönünden incelediğimiz entegre raporların, tüm içerik ögelerine yönelik açıklamalara yer verdiği görülmektedir. Entegre raporlar, diğer raporlama türlerinden bilgileri de bünyesinde barındırmakta ve hatta sık sık ilgili raporlara atıfta bulunmaktadır. Entegre raporlamanın işletme hakkında bütüncül bir bakış açısı sunduğu ve daha çok gelecek yönelimli bir raporlama yaklaşımı olduğu açıktır. 


\subsubsection{Kelime S1kl1kları Analizi}

Nitel araştırmalarda kullanılan bu yöntemle tekrar eden kelimelerden hareketle hangi konunun ne düzeyde açıklandığı belirlenebilmektedir. Çalışmada 50 işletmenin yayınladığ 1 raporların her biri için ve genel olarak 50 raporun tamamına yönelik olarak kelime sıklıkları belirlenmiş ve kelime bulutları oluşturulmuştur. En az üç harften oluşan sözcükler aramaya dâhil edilmiştir. İşletme adı, yıl, milyon gibi ifadeler göz ardı edilmiştir 50 raporun tamamına ilişkin kelime bulutu aşağıdaki şekilde yer almaktadir.

50 raporun tamamına ait sözcük bulutu Şekil 1'de verilmiştir.

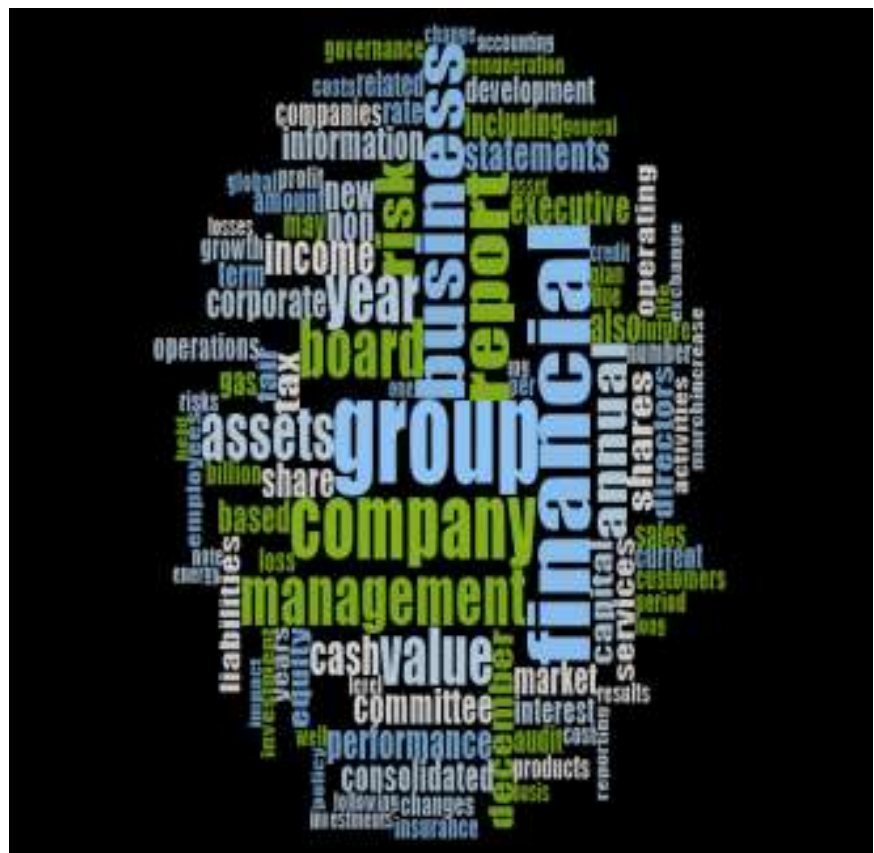

Şekil 1. 50 Raporun Tamamına İlişkin Sözcük Bulutu

Şekil 1 incelendiğinde 50 raporun tamamına ilişkin grup, şirket, rapor, iş/işletme, yönetim kelimelerinin sıkça tekrarlandığı görülmektedir. 50 raporun tamamı göz önüne alındığında en çok atıfta bulunulan 10 sözcük ise şu şekilde gerçekleşmiştir:
Tablo 3. 50 Rapora İlișkin En Sık Tekrarlanan 10 Sözcük

\begin{tabular}{lllll}
\hline $\begin{array}{l}\text { Sözcük } \\
\text { (İngilizce) }\end{array}$ & $\begin{array}{l}\text { Sözcük } \\
\text { (Türkçe) }\end{array}$ & $\begin{array}{l}\text { Karakter } \\
\text { Sayısı }\end{array}$ & $\begin{array}{l}\text { Atıf } \\
\text { Sayısı }\end{array}$ & \% \\
Group & Grup & 5 & 22688 & 0.64 \\
Financial & Finansal & 9 & 21357 & 0.60 \\
Company & Şirket & 7 & 17053 & 0.48 \\
Business & İş/̧̇sletme & 8 & 16611 & 0.47 \\
Report & Rapor & 6 & 15680 & 0.44 \\
Board & Kurul & 5 & 13537 & 0.38 \\
Management & Yönetim & 10 & 13246 & 0.37 \\
Value & Değer & 5 & 12949 & 0.37 \\
Risk & Risk & 4 & 12674 & 0,36 \\
Assets & Varlıklar & 6 & 12616 & 0,36 \\
\hline
\end{tabular}

\section{Sonuç}

İşletme faaliyetlerine ilişkin bilgiler kurumsal raporlar vasıtasıyla sunulmaktadır. İşletme faaliyetlerinin şeffaflık ve hesap verilebilirliğini sağlamada etkin rol oynayan kurumsal raporlar, finansal performans sonuçlarının sunulduğu finansal raporlar ile sosyal, kurumsal ve çevresel performans sonuçlarının yer aldığı diğer çeşitli raporları ifade etmektedir. Tüm bu raporların temelinde yer alan finansal raporlar, sadece finansal performans sonuçlarını sunmakta ve bu performansa etki eden diğer faktörleri açıklamamaktadır. Diğer kurumsal raporlama türleri ise finansal sonuçlar üzerinde yaratılan etkiyi tam olarak açıklayamamaktadır. Bu durum işletme bilgilerine ihtiyaç duyan kesimlerin birden fazla rapora başvurmasını gerektirmektedir. Özellikle yatırımcıların işletme hakkında tek bir rapordan bilgi sahibi olmak istemesi ve finansal performans sonuçları ile bu performansa etki eden sosyal, kurumsal ve çevresel faaliyetlerin bir arada sunulması fikri geniş destek görmüştür. Bu amaçla tüm bu isteklerin yerine getirilmesine imkan sağlayan entegre raporlama düşüncesi ortaya çıkmıştır.

Çalışmada 2016 yılında Fortune Global 500 listesinde yer alan işletmelerin 2016 yılı entegre raporları içerik analizi ile incelenmiştir. Entegre rapor yayınlayan işletmelerin yayınladıkları raporlar, içerik ögeleri yönünden analiz edilmiştir. İşletmelerin hangi içerik ögesini ne düzeyde açıkladığına yönelik olarak gerçekleştirilen araştırmanın sonuçları şöyledir:

1. İşletmeler yayınladıkları raporlarda tüm içerik ögelerine yönelik açıklama yapmalarına karşın en çok açıklama Kurumsal Genel Görünüm ve Dış Çevre içeriğine yöneliktir. $\mathrm{Bu}$ durum işletmelerin, kurumsal yapısı, yönetimi, işletme kültürü, etik anlayışı, faaliyet gösterdiği pazarları, rekabet ve pazar konumu ile ilgili bilgileri açıkladıklarını göstermektedir.

2. İşletmelerin faaliyet gösterdikleri alanlar farklı olmasına rağmen, her işletmenin kendine uygun bir iş modeli geliştirdiği ve buna ilişkin bilgileri raporlarda sunduğu görülmektedir. 
3. İşletmeler finansal performans sonuçlarına etki eden tüm faktörleri ve bunların etkilerini raporlarda açıklamaktadır.

4. İşletmeler finansal raporlarda sundukları bilgileri entegre raporlarında özet bir şekilde ve herkesin anlayacağı bir dil ile sunmaktadır.

5. İşletmelerin geçmişteki performansının yanında gelecekte ne tür bir performans göstereceği, buna ilişkin hedefleri ve bu hedefleri gerçekleştirmek için kullanacağı kaynakların tahsisi gibi konulara da raporlarda yer verilmektedir.

6. İşletmelerin başlangıçtaki sermaye ögelerinin işletme faaliyetleri sonucundaki durumuna ilişkin açıklamalar, işletmeye sermaye sağlayanların sağladıkları fonların durumunu göstermesine yardımcı olacak şekilde sunulmaktadır.

7. İşletmeye yatırım yapmak isteyen yatırımcıların özellikle merak ettiği, işletmenin sürdürülebilirliği, mevcut risklerin durumu, işletmenin risk yönetim stratejileri gibi konulara raporlarda yer verilmektedir.

8. İşletmelerin izlediği politikaların etkinliğinin ve işletme verimliliğinin ölçülmesinde izlenen yöntemler hakkında raporlarda açıklama yapılmaktadır.

9. Entegre raporlarda en s1k geçen kelimeler incelendiğinde, işletme adı ve diğer bilgileri dışında, yönetim, rapor, kurul ve finansal kelimelerinin geçtiği görülmektedir. Buradan hareketle raporlarda işletmenin yönetim anlayışı ve yapısı, yönetim kurulu ve işletme ile ilgili diğer kurullara ait bilgiler ve finansal bilgilere yönelik açıklamaların ön planda olduğu söylenebilir.

10. Raporlarda yer alan bilgilerin güvenilirliği konusunda izlenen politika ve standartlara ilişkin açıklamalara yer verilerek, rapor hakkında güvence sunulmaktadır.

Ülkemizde entegre raporlama uygulamalarının geliştirilmesi ve raporlama yapan İşletme sayısının çoğalması, entegre raporlama konusunda kamu ve özel kesimin desteği ile mümkün olacaktır. Bu nedenle entegre raporlamanın yaygınlaştırılmasına yönelik faaliyetlerin desteklenmesi gerekmektedir. Dünya genelinde faaliyet gösteren işletmelerin entegre raporlarını incelediğimiz bu çalışma, hem entegre raporlama yapacak olan işletmelerimize hem de literatüre katkı sağlayacaktır. Bu çalışmanın, yayınlanan raporların incelenmesi ile sunulacak raporların ve bu konuda yapılacak çalışmaların gelişmesine olumlu etki yapması beklenmektedir. Ülkemizde entegre raporlama yapan işletme sayısının artması ile birlikte bu çalışmanın ülkemizde yayınlanan entegre raporlara uygulanması yeni bir çalışma konusu olarak düşünülebilir. Böylelikle bu çalışma sonuçları ile yapılacak çalışmanın sonuçlarının karşılaştırılması hem uygulayıcılar açısından hem de akademik camia açısından anlamlı sonuçlar ortaya çıkarabilecektir.

\section{Kaynakça}

Adams, S., \& Simnett, R. (2011). "Integrated Reporting: An Opportunity for Australia's Not-for-Profit Sector". Australian Accounting Review, 21(3), ss.292301. doi:10.1111/j.1835-2561.2011.00143.x.
Ala, T. Kahraman, T. \& Sümer, E. (2016). "Muhasebe Bilgi Kalitesi: Karşılaştırılabilirlik Kavramı”, Süleyman Demirel Üniversitesi Sosyal Bilimler Enstitüsü Dergisi, ss.140-152.

Altınay, A.T. (2016) “ Entegre Raporlama Ve Sürdürülebilirlik Muhasebesi”, Süleyman Demirel Üniversitesi Sosyal Bilimler Enstitüsü Dergisi, 25, ss.47-64.

Arac1, H. \& Yüksel, F. (2017). "Entegre Raporlamada Muhasebe Meslek Mensuplarının Rolü Ve Muhasebe Müfredatlarında Entegre Raporlama", Muhasebe Bilim Dünyası Dergisi, 19(2), ss.389-414.

Aras, G. \& Sarığlu G.U. (2015). "Kurumsal Raporlamada Yeni Dönem: Entegre Raporlama”, Tüsiad.

Aydın, S. (2015), Entegre Raporlama, Türkmen Kitabevi, İstanbul.

Aysan, Mustafa A. (2007), "Muhasebe ve Kurumsal Yönetim", Muhasebe ve Finansman Dergisi, ss.17-24.

Barth M. E., Cahan S.F., Chen L.\&, Venter, E. R. (2017) "The Economic Consequences Associated With Integrated Report Quality: Capital Market And Real Effects", Accounting, Organizations And Society, 6243-64. doi:10.1016/j.aos.2017.08.005.

Bhatt, G. (2002), "Managing Strategies For Individual Knowledge And Organizational Knowledge", Journal of Knowledge Management, 6 (1).

Bobitan, R., \& Stefea, P. (2015). "Integrated Reportıng - A More Holistic Picture For A Company", Annals Of The University Of Oradea, Economic Science Series, 24(2), ss.448-456.

Buitendag, N., Fortuin, G.S. \& De Laan, A., (2017), “Firm Characteristics And Excellence In Integrated Reporting", South African Journal of Economic and Management Sciences $20 \quad$ (1), a1307. https://doi.org/10.4102/sajems.v20i1.1307

Cochrane, P. (2006), "Exploring Cultural Capital and Its Importance in Sustainable Development", Ecological Economics, 57 (2), ss. 318-330.

Dinçer, Ö. (1991), Stratejik Yönetim ve İşletme Politikası, Timaş Yayınları, İstanbul.

Eccles, R. \& Krzus, M. (2010), One Report: Integrated Reporting for a SustainableStrategy, United States of America: John Wiley \& Sons.

Eccles, R. G. \& Saltzma, D. (2011), “Achieving Sustainability Through Integrated Reporting”, Social Innovation Review, ss. 56-61.

Eccles, R.G., \& Serafeim, G. (2015). Corporate and integrated reporting: A functional perspective. In $\mathrm{S}$. Mohrman, J. O'Toole, \& E. Lawler (Eds.), Corporate stewardship: Organizing for sustainable effectiveness. Sheffield, UK: Greenleaf Publishing.

Fasan, M., Mio, C. \& - Pauluzzo, R. (2016), “Internal Application of IR Principles: Generali's Internal Integrated Reporting', Journal of Cleaner Production, ss. $1-42$. 
Frias-Aceituno J, Rodriguez-Ariza L \& Garcia-Sanchez IM. (2012). "The role of the Board in the dissemination ofintegrated corporate social reporting", Corporate Social Responsibility and Environmental Management, 20(4), ss. 219-233

Gençoğlu, Ü. \& Aytaç, A. (2016), “Kurumsal Sürdürülebilirlik Açısından Entegre Raporlamanın Önemi ve BIST Uygulamalar1", Muhasebe ve Finansman Dergisi, Ekim, ss.51-66

Hurghis, R., (2017). "Integrated reporting and board features", Audit Financiar, 15, 1 (145), ss.83-92, ISSN: $1583-5812$; ISSN on-line: 1844-8801.

International Integrated Reporting Council (IIRC) (2011), "Towards integrated reporting. Communicating value in the 21st century", available at: www.iirc.org (Erişim tarihi: 2016).

International Integrated Reporting Council (IIRC) (2013), "The international IR Framework", available at: www.theiirc.org/international-ir-framework/ (Erişim tarihi: 2016).

Ivanovna, G. O. (2016), "Prospects For Compılation Integrated Reporting Credit Unions" Economic Processes Management, ISSN 2311-6293.

Kanzer, A.M. (2010), "Toward a Model for Sustainable Capital Allocation": ss. 45-57; Edited by: Eccles, R.G., B. Cheng ve D. Saltzman. 2010. The Landscape of Integrated Reporting Reflections and Next Steps, Harvard Business School.

Karğın S., Aracı, H. \& Aktaş, H. (2013) "Entegre Raporlama: Yeni Bir Raporlama Perspektifi", Muhasebe ve Vergi Uygulamaları Dergisi, (1), ss.2746.

Kaya, U., Aygün, D. \& Yazan, Ö. (2016), "Yeni Bir Kurumsal Raporlama Yaklaşımı Olarak Entegre Raporlama Ve Dünyadaki Uygulamaları Üzerine Bir Araştırma" KTÜ Sosyal Bilimler Dergisi, 6 (11), ss.85-101.

Kaya, H.P. (2015), "Entegre Raporlama Sisteminin Ortaya Çıkış Sebepleri Ve Şirketlere Sağlayacağı Faydalar”, Muhasebe Ve Denetime Bakış, Haziran, ss.113-130.

Küçükgergerli, N. (2017), Entegre Raporlama Endeksi, Türkmen Kitabevi, İstanbul.

Lai A., Melloni, G. \& Stacchezzini, R. (2016) “Corporate Sustainable Development: is 'Integrated Reporting' a Legitimation Strategy?", Business Strategy and the Environment, 25, ss. 165-177, DOI: 10.1002/bse. 1863 .

Laudon, K. \& Laudon, J. (1998), Management Information Systems, USA: Prentice Hall İnternational Inc.

Maniora, J. (2017). "Is Integrated Reporting Really the Superior Mechanism for the Integration of Ethics into the Core Business Model? An Empirical
Analysis", Journal Of Business Ethics, (4), 755. doi:10.1007/s 10551-015-2874-z.

Melloni, G., Stacchezzini, R. \& Lai, A. (2016), “The Tone Of Business Model Disclosure: An Impression Management Analysis Of The Integrated Reports", Journal of Management \& Governance., 20 (2), ss.295-320. DOI 10.1007/s10997-015-9319-z.

Özdemir, F. S. (2013). "Finansal Bilginin Kapsamı Ve Finansal Bilgi Türlerinin Sınıflandırılmasına Yönelik Bir Öneri”, MÖDAV, ss.155-175.

Sierra-Garcia, L., Zorio-Grima, A., \& Garcia-Benau, M. A. (2015). "Stakeholder Engagement, Corporate Social Responsibility and Integrated Reporting: An Exploratory Study", Corporate Social Responsibility AndEnvironmental Management, (5), ss.286-304, doi:10.1002/csr.1345.

Smith, Sean Daniel S. (2015), "Effect Of Integrated Reporting On Financial Performance”, Yayınlanmamış Doktora Tezi, Capella University.

Stacchezzini, R., Melloni, G., \& Lai, A. (2016). "Sustainability Management And Reporting: The Role Of Integrated Reporting For Communicating Corporate Sustainability Management". Journal Of Cleaner Production, ss.102-109, doi:10.1016/j.jclepro.2016.01.109.

Stewart, T. A. (1997), Entelektüel Sermaye Örgütlerinin Yeni Zenginliği, Çeviri: Elhüseyni, N., MESS Yayınları, İstanbul.

Şamiloğlu, F. (2002), Entelektüel Sermaye, Gazi Kitabevi, Ankara.

Ştefănescua, C. A., Oprişora, T. \& Sîntejudeanua, M. A. (2016). "An original assessment tool for transparency in the public sector based on the integrated reporting approach" Accounting and Management Information Systems, 15, (3), ss. 542-564.

Tianyuan Feng, Lorne Cummings, Dale Tweedie, (2017) "Exploring integrated thinking in integrated reporting - an exploratory study in Australia", Journal of Intellectual Capital, 18 (2), ss.330-353, https://doi.org/10.1108/JIC-06-2016-0068

Van Bommel K. (2014). "Towards a legitimate compromise?: an exploration of Integrated Reporting in the Netherlands". Accounting, Auditing and Accountability Journal, 27(7), ss. 1157-1189.

Yılmaz, B., Atik, M. \& Okyay, A. (2017) "Geleceğin Raporlama Sistemi: Entegre Raporlama", Muhasebe Ve Denetime Bakış Dergisi, (52), ss. 95-108.

Yüksel, F. (2017), Entegre Raporlama, Ekin Basım Yayın Dağıtım, Bursa.

http://www.entegreraporlamatr.org (Erişim Tarihi: 22.10.2017)

http://www.tdk.gov.tr/ (Erişim Tarihi: 15.01.2017) 